\title{
Effect of Objectives and Key Results (OKR) on Organisational Performance in the Hospitality Industry
}

\author{
Pureheart Ogheneogaga IRIKEFE a \\ E-mail: donpheart@yahoo.com | Phone No.: +2347033515221 \\ a Department of Business Administration, Bingham University, Karu, Nasarawa State
}

\begin{abstract}
The study investigated the effect of Objectives and Key Results (OKR) management technique on organisational performance in the hospitality industry using hotels in Abuja, Nigeria. The study utilised a survey research design; where primary data were collected from a sample of 207 employees of hotels in the metropolis of Abuja. The questionnaires used to collect the data contained closed-ended questions that were rated on a Likert-5-point scale of "Strongly Agree, Agree, Neutral, Strongly Disagree and Disagree." Using factor analysis, the questionnaire was adjudged to have good measurement quality, and thus suited for investigating the study variables. Furthermore, based on the rotated component matrix, the Measurement of Sampling Adequacy (MSA) for all 37 questions was found to be more than 0.7 on aggregate. The data was then analysed with the aid of PSA correlation and regression statistical tool. Arising from the result, the model was significant at 0.000 and the null hypothesis was rejected. The study concluded that OKR has a positive significant effect on organisational performance. From the findings, hotels fulfilled their goals by using OKR practices, which requires managers to collaborate with their subordinates to define and clarify performance goals and key results that are aligned with the work unit's and the organization's overall goals. The study, therefore, recommends the activation and implementation of OKRs in hotel establishments due to its numerous benefits that help to the positive development of the organization's performance.
\end{abstract}

Key Words: Objectives and Key Results, Management by Objectives (MBO), Hospitality Industry, Organisational Performance, Goal Setting.

\section{Introduction}

Objectives and Key Results (OKR) is a contemporary framework for management that involves setting, communicating and monitoring monthly (conventionally trimestral) goals and results in organisations. The aim of OKR is to link company, team and personal objectives in a structured manner, in the form of measurable results, that causes all staff to work together in a unified direction (Niven \& Lamonte, 2017). From the 1950s, business managers have embraced varieties of management techniques with the intent to improve staff performances. Peter Drucker (1909-2005) introduced Management by Objectives (MBO) - a process where managers and employees work together to set, record and monitor goals for a specific period, often annually. In the early 1980s, Key Performance Indicators (KPI) and SMART goals as introduced by George T. Doran (19392011), became prevalent approaches for organisations to set objectives. However, in 1999, John Doerr, bestselling author of "Measure What Matters" (2017), introduced Objectives and Key Results (OKR) to Google, an idea he first learned about at Intel Corporation, which modernised goal setting. Today, OKRs are into all intents and purposes, an effective standard for aligning company and individual goals-achieving goal congruence (Duggan, 2015).

The hospitality industry, however, applies to nearly any company that is focused on customer satisfaction. While this industry is very broad, some defining facets include restaurants, hotels, taverns and bars, amusement parks, cinemas, transportation and every aspect of the tourism industry (Adeola \& Ezenwafor, 2016). Hess (2017), averred that one of the major challenges managements of restaurants face is finding time to set concrete and achievable goals. Hess (2017), also claimed that, if one is in the hospitality industry, he or she likely find out that, the drudge of the day-to-day tasks therein, tends to outwit long-term growth strategy and to succeed in the industry, there is a need to set timely objectives which are tied to results. Meanwhile, OKR is not only a recent goal-setting methodology driven by outcomes, they are built to grow with organisations and provide alignment to strategic objectives along the way.

It has been observed that the management of some hospitality businesses in Abuja, Nigeria lack ample utilisation of techniques to make them manage well. This is because there has been an increasing case of mass IJRP 2021, 91(1), 185-195; doi:10.47119/IJRP1009111220212596 
staff turnovers, low business lifespans, outright wind-up amongst others. Whilst some hospitality businesses utilised frameworks such as OKR and MBO, the empirical effect of these management techniques appears to be unclear. First Round Review (2015), averred that OKR is been used by .com companies such as Uber, Google, Twitter, and LinkedIn, as such, it is undecided if the OKR management technique is effective in the hospitality sector. Some of the studies that assessed the OKR technique in the hospitality industry did not show empirical evidence (Pizam \& Shani, 2009; Gilb, 2017). Meanwhile, studies that carried out empirical research such as Holliman (2015) and Teo and Low (2016), either did not use the adequate statistical tool or revealed that OKR is not as effective. As such, there remain knowledge, empirical and application gaps with regards to OKR.

The objective of this research is to assess the effect of objectives and key results (OKR) management techniques on organisational performance in the hospitality industry. The scope of the study covers hotels that apply similar management and goal setting techniques in the metropolis of Abuja municipal, Nigeria. The study hypothesised that there is no significant effect of objectives and key results (OKR) management technique on organisational performance in the hospitality industry.

\section{Literature Review}

\subsection{Objectives and Key Results (OKR)}

Pragmatically, the OKR management technique as a concept comprises three significant words viz. 'Objectives,' 'Key' and 'Results'. The Business Dictionary (2007), defined Objectives as specific results that an individual or system aims to achieve within a time frame and with available resources; Key in this sense, is synonymous to importance or significance; whilst Results, as defined by Business Dictionary is consequence, outcome, or conclusion of a problem, probe or experiment after a while. Arising from the aforementioned definitions, OKR strictly refers to a management framework that is applied to bring about significant unambiguous consequence, outcome, or conclusion of a problem that an individual or organisation aims to achieve or surpass within a time frame and with existing resources. However, OKR is defined by most other authorities to reflect aspects of the operationalisation of the management technique.

As earlier mentioned, Niven and Lamonte (2017), defined OKR as a contemporary framework for management that involves setting, communicating and monitoring monthly goals and results in organisations. Whereas Kaljundi (2014), opined that OKR is a critical thinking framework and ongoing discipline that seeks to ensure employees work together, focusing their exertions to make quantifiable contributions that drive the company forward.

According to Wodtke (2016), OKR encompasses a system used to focus a group or individual around a bold goal, wherein objectives are used to set the goal for a set period, usually monthly or a quarter, as result, the key results serves as tell-tale signs if the objective has been met by the end of the time. This further goes to show that OKR is a critical thinking framework and ongoing discipline that seeks to ensure employees work together, converging their efforts to make quantifiable contributions to achieve a goal. Wodtke (2016), averred that OKRs are embraced by companies for one of three key reasons viz. focus, alignment and acceleration, but just like new technologies, methodologies can equally suffer from the hype cycle (as in Figure 2.1.), and OKRs are no exception.

Figure 2.1. Gartner's hype curve



Source: Wodtke, 2016. 
Wodtke (2016), averred that to maximise OKRs, there are three approaches one can adopt viz. starting with only one OKR for the company; having one team adopt OKRs before the entire company does and; begin applying OKRs to projects to train people on the objective-result approach. In comparing OKR to Management by Objectives (MBO), OKR is a much newer framework which was why Wodtke (2016) took cognisance of the Gartner's Hype Curve. Furthermore, whilst MBO set and monitors goals annually, OKR monitors monthly (conventionally trimestral) goals and results. Albeit on the surface, OKR may seem to be more complicated than MBO, ultimately, OKR encompasses providing tactical plans towards achieving goals whilst focusing on teamwork, community engagement and organisation-wide goals instead of individual performance.

\subsection{Organisational Performance and the Hospitality Industry}

Organizational performance refers to the performance of an organization as compared to its goals and objectives (Cho \& Dansereau, 2010). According to Tomal and Jones (2015), it involves the actual results or output of a company as measured against that organization's intended outputs. The effectiveness of any corporation consists of the efficiency of every one of its employees; thus, employee performance is often defined, in part, as a function of its management (Mastrangelo, Eddy \& Lorenzet, 2014). Particularly, employee performance will be managed by manipulating the factors on which it depends. These factors include a large range of variables in line with the goals and objectives of the organisation. However, employers do not necessarily possess the facility to affect all of those variables. For instance, it is often impossible to influence age, seniority or the private goals of workers (Cho \& Dansereau, 2010). However, some factors are subject to the assessment by employers seeking higher organization performance - these are the key results. Furthermore, the viability of the organization is determined by whether or not profits are economically sustainable and clients are satisfied. Nevertheless, the importance of organizational performance within the hospitality industry has received considerably little attention.

Meanwhile, the hospitality industry is an umbrella term covering a variety of industries, comprising hotels, restaurants, travel management bodies and resorts (Popova, 2012). It also refers to other kinds of institutions that offer shelter or food or both to people away from their homes (Lauková, 2006). Hogan (2011), opined that the hospitality industry has evolved dramatically in the last generation, and there are ways to address key result areas and objectives which includes the necessary balance of technology and personal interaction, as a result, OKR techniques are paramount frameworks for management in the sector hitherto. In a case where business travel from the low levels of occupancy and some (little) degree of revenue growth of the past 24 months, there will be a tendency to reset goals and objectives in more positive and aggressive ways. Hogan (2011), further explained that OKR contains activities that support objectives that can be identified in the measurements, along with the specific figures, dates or other ways agreed upon as noting progress and successes.

According to Baker et al (2011), the hospitality industry provides services for people who are away from their household notwithstanding if it is for long or short periods, such that these services can vary agreeing to the specific needs of both an individual away from home and the organisation operating those services. The industry is significant owing that it contributes to the growth of an economy by providing a lot of employment opportunities for the citizenry of a State. Also, backing huge percentage of a nation's gross domestic product, thereby helping to raise the national income and by earning foreign currencies through the goods and services provided to visitors, whilst improving the balance of payments (Baker et al, 2011). This goes to explain that the significance of the hospitality industry, requires established management techniques to achieve key results. According to PFK Consulting (1997), with key results and objectives, the aggressive hospitality industry will be dynamic in pricing its products and services due to the increasing demand for such products and services.

\subsection{Empirical Review}

While there are several well-known techniques in academia, only a minority of them have gained prominence among the business teams; OKR is one such emerging framework (Pawar, 2016). Caan (2014), carried out a study on his formal sandwich chain, Benjy, which had 400 employees in 65 outlets. The study was prompted because, after six months of running the business, he had to resell and lost several million pounds in the process. Caan (2014), averred that even as a successful entrepreneur, and hitherto employing various management techniques within the short time, he was ill-equipped to go into a market he did not sufficiently assess, his lesson was that there was the need to research the sector, gather experience and focus on the customers, whilst setting timely objectives, to succeed in it.

Crawford and Hubbard (2008), assessed the impact of work-related goals on hospitality industry employee variables. They assessed employee outcomes such as intention to quit, job involvement, intrinsic work 
satisfaction, organisational commitment and organisation-based self-esteem. Their findings revealed that employees who followed established work-related goal-setting framework experienced greater, job involvement, intrinsic work satisfaction, organisational commitment and organisation-based self-esteem while being less likely to quit their jobs. Whilst their hypotheses were developed from a sound theoretical framework similar to that of the OKR, their method of analysis was not adequate to draw a cause-and-effect inference of the study variables. Similarly, Chathoth and Olsen (2007), sought to investigate the use of a common goal-setting strategy to maximise revenue in the hotel industry. They explored scientific technique that combines goal setting, operational research, statistics and customer relationship management and categorises customer into price bands based on various services. They concluded that revenue management will bring higher efficiency and increased profitability if management set up a framework that is goal-oriented towards satisfying customers. Whilst Chathoth and Olsen (2007), used a suitable method of analysis, the reliability of their research instrument was not tested.

Holliman (2015), assessed OKR and MBO as still effective; particularly, the research was regarding its use and/or usefulness by urban districts. Holliman (2015), explored its relevance together with other management models in his doctoral dissertation. Findings included exclusive use by $3 \%$ of the 893 survey respondents and use together with other techniques by $14 \%$ of the respondents. In effect, $\mathrm{MBO}$ is employed in some form by $17 \%$ of the urban districts, cutting across the hospitality sector. Furthermore, its usefulness as a way for enhancing internal control was found to be slightly useful with a mean rating of 4.06 on a six-point Likert scale, supported all responses, and 4.54 (between slightly useful and moderately useful) when considering valid responses for cities using that system only. Holliman (2015), inferred that though the MBO technique continues to be quite effective, other improved management techniques like OKR may yield a more positive result. Even though Holliman (2015) did an elaborate study on MBO, his inference on OKR was based on the $\mathrm{R}^{2}$ not accounted for and this could imply lots of frameworks that may or may not include the OKR.

Teo and Low (2016), examined whether designated goal-setting frameworks like OKR have an impact on employee effectiveness and ultimately improve organisation effectiveness. They used XYZ (Singapore) Pte Ltd, which is a Hi-Tech semiconductor test systems and equipment company in Singapore as a case study. The findings of their empirical research suggested that there was unanimous concurrence amongst the research interview participants that goal setting has an impact on employee effectiveness and ultimately improves organizational effectiveness. The works of Teo and Low (2016) was robust in theory, but they failed to use adequate statistical tool to test their hypotheses. They use simple percentages as a means to draw inference which does not suffice in showing significance.

Gilb (2017), carried out exploratory research on OKR what is wrong and how to fix it. He concluded that OKR more or less has to do with systematic thinking and planning, however, it has several built-in problems, preventing it from being as good as it claims. He identified that limited case studies and documentation to give credence to OKR claims is a major challenge. Furthermore, Gilb (2017), limned that conspectus of the limitations of OKR will be eliminated if the following steps were to be followed, which are: All OKR will be quantified, if they are 'progresses'; all OKR will explicitly cross-index higher-level goals or ideas which they pretend to support; quantified levels of any objective or key result are permitted like past, tolerable, wish, stretch; the only valid measure of 'good work' should be the actual measurement of improvement of the Objective, in the direction of a constraint (tolerable) and a target (wish, stretch); for serious and critical work, and Impact Estimation Table can be used to get a better overview of how all key results affect all related objectives; stakeholders involved for any OKR should be listed. The argument of Gilb (2017), was based on the precision of OKR methodology to avoid vagueness, and as such, qualitative data collected was converted to quantitative data using Likert scaling in this research.

Also, arising from the empirical reviews of some of the literature in this section, the researcher built on the work done by Holliman (2015), with emphasis on OKR, focusing on the specific components of MBO which are embodied (replicated) in OKR, thus giving credibility to MBO as a root system. Holliman (2015), equally averred that additional research of the components of MBO used by cities today may indicate more precise data as to what elements of MBO are useful and thriving in present municipalities. As aforementioned, this study was carried out in Abuja Municipal, centring on the hospitality industry.

\subsection{Theoretical Framework}

Many past management theorists devised terms and ideas that oppose contemporary management styles, however Peter Drucker (1909-2005), known as the father of contemporary management, formulated a theory in 1954 that is still used today, this theory is noted as the "Management Theory of Peter Drucker" (Caramela, 
2018). According to Drucker (1954), managers should, above all, be leaders, and instead of setting stringent hours and discouraging innovation, they should encourage a more flexible, collaborative approach. The Management Theory of Peter Drucker placed high importance on decentralisation, knowledge work, and management by objectives (MBO) amongst others. Arising from the speculation, Drucker (1954), averred that $\mathrm{MBO}$ is that the process of developing aims in an exceedingly company to supply a way of direction to the workforce, it involves developing the objectives enabling the workers to know their contribution at the workplace. Drucker (1954), gave five steps of achieving MBO and averred that the fundamental principle is growth and development, not punishments, they are: objectives are determined with the employees; objectives are formulated at both quantitative and qualitative levels; objectives must be challenging and motivating; daily feedback on the state of affairs at the amount of coaching and development rather than inert management reports; rewards (recognition, appreciation and/or performance-related pay) for achieving the intended objectives may be a requirement.

In 1968, Edward Locke presented a study in a writing, "Towards a theory of task motivation and incentives." Arising from the findings, the goal-setting theory came into existence. Locke (1968), summarised and integrated research concerned with the connection between conscious goals and intentions and task performance. The ideology behind the research was that a person's conscious ideas regulate his actions. Locke (1968), cited studies covering tough goals produce a better level of performance (output) than easy goals; precise tough goals produce the next level of output than a goal of "do your best;" and behavioural intentions regulate choice behaviour. The speculation also viewed goals and intentions as mediators of the consequences of incentives on task performance. Locke (1968), showed evidence supporting the view that monetary incentives, points in time, and knowledge of results do not affect performance level independently of the person's goals and intentions. Locke (1968), equally disbursed a theoretical analysis supporting the identical view with relevance to three other incentives: competition, participation, and acclamation or reproof. Lastly, behavioural intentions were found to arbitrate the consequences of cash and "verbal reinforcement" on choice behaviour. It was concluded that any adequate theory of task motivation must realize the individual's conscious goals and intentions.

In 1988, Andrew Grove came up with a theory in his book "High Output Management," that became a highly effective framework for setting, measuring, and tracking goals in an organisation. This theory was formed supported inferences from the works of Drucker (1954), and Locke (1968), the idea is stated as Objectives and Key Results (OKR). According to Grove (1983), any effective system that has roots in management by objectives (MBO) needs only to answer two questions: Where do I would like to go? (The answer provides the Objective); how will I pace myself to determine if I am getting there? (The answer gives us milestones or Key Results). This theory forms the basis wherein this research will rest on, to be administered in Abuja Municipal, whilst centring on the hospitality industry.

\section{Methodology}

The study adopted the survey research design of which relies on responses gotten from primary data. The sample size of the study comprised 207 management and operational level employees of hotels in the metropolis of Abuja municipal, Nigeria. Purposive sampling techniques was adopted as it is one in which the researcher selects a sample consisting of only those sampling units which are in line with the research variable-OKR. The questionnaires used to collect the primary data comprised of close-ended questions and had answer options like "Strongly Disagree =1, Disagree =2, Neutral =3, Agree =4, Strongly Agree $=5$." It was divided into two sections viz. Personal data; and Research Question (Objectives and Key Results $=$ OKR and Organisational Performance $=\mathrm{OP})$. The questionnaire used in this study was analysed using factor analysis. The data obtained from the administration of questionnaires to the respondent were analysed with correlation and regression analyses. Meanwhile, all statistical data analyses were performed using SPSS version 25.0 (IBM Corp, 2017).

Table 3.1.: Factor analysis for the questionnaire

\begin{tabular}{|c|c|c|c|c|}
\hline \multicolumn{3}{|c|}{ Variables } & OKR & OP \\
\hline \multirow{4}{*}{  } & OKR1 & Developing the hotel's goals in light of modern technologies. & 0.646 & 0.119 \\
\hline & OKR2 & Keeping and inspiring employees to achieve hotel goals on a continuous basis. & 0.898 & 0.196 \\
\hline & OKR3 & $\begin{array}{l}\text { Building shared decision-making and peer support among individuals with } \\
\text { adequate authority and responsibility for effective management by the } \\
\text { organization. }\end{array}$ & 0.869 & 0.147 \\
\hline & OKR4 & $\begin{array}{l}\text { Unleashing the potential that currently exists in the workforce with objectives } \\
\text { and key results (OKR) technique. }\end{array}$ & 0.921 & 0.173 \\
\hline
\end{tabular}




\begin{tabular}{|c|c|c|c|c|}
\hline \multicolumn{3}{|c|}{ Variables } & \multirow{2}{*}{$\frac{\text { OKR }}{0.900}$} & \multirow{2}{*}{$\mid \mathbf{O P}$} \\
\hline & OKR5 & $\begin{array}{l}\text { The efficiency with which the hotel services development strategy was carried } \\
\text { out involves OKR. }\end{array}$ & & \\
\hline & OKR6 & Aligning individual goals with organisational goals. & 0.848 & 0.327 \\
\hline & OKR7 & Designing, implementing and assessing the hotel's objectives. & 0.726 & 0.198 \\
\hline & OKR8 & $\begin{array}{l}\text { Developing the organizational structure and operational procedures for } \\
\text { employee evaluations. }\end{array}$ & 0.670 & 0.551 \\
\hline & OKR9 & Because your hotel implemented OKR, it is fulfilling its goals and your goals. & 0.878 & 0.094 \\
\hline & OKR10 & A team that is respected, energized, and capable of achieving goals. & 0.748 & 0.093 \\
\hline & OKR11 & $\begin{array}{l}\text { Activating workers' and the community's active participation in hotel } \\
\text { management. }\end{array}$ & 0.789 & 0.030 \\
\hline & OKR12 & $\begin{array}{l}\text { Employees' readiness to seek feedback monthly as against annually or never on } \\
\text { their own job performance. }\end{array}$ & 0.701 & 0.354 \\
\hline & OKR13 & Staff taking proactive actions to boost their own development. & 0.850 & 0.150 \\
\hline & OKR14 & $\begin{array}{l}\text { Staff adherence to hotel policies, which can be seen in all aspects of daily } \\
\text { operations. }\end{array}$ & 0.617 & 0.202 \\
\hline & OKR15 & $\begin{array}{l}\text { Goal-oriented management provides a better chance of continuing to be } \\
\text { successful in employee achievement. }\end{array}$ & 0.858 & 0.235 \\
\hline & OKR16 & Goal-oriented management adds to true employee decision-making autonomy. & 0.756 & 0.023 \\
\hline & OKR17 & $\begin{array}{l}\text { To what extent do you believe employee motivation influences work } \\
\text { productivity or performance? }\end{array}$ & 0.775 & 0.021 \\
\hline & OKR18 & $\begin{array}{l}\text { Is it true that objectives and key results (OKR) technique aids in obtaining entire } \\
\text { commitment from all employees to collaborate toward a common goal? }\end{array}$ & 0.895 & 0.214 \\
\hline \multirow{19}{*}{ 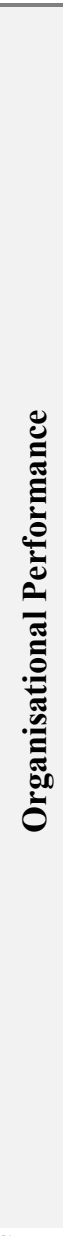 } & OP1 & $\begin{array}{l}\text { Do you believe that providing employees with a good and timely wage } \\
\text { promotes employee and organizational performance in terms of attaining a } \\
\text { common goal? }\end{array}$ & 0.140 & 0.523 \\
\hline & OP2 & $\begin{array}{l}\text { eve that timely promotion promotes employee and organizational } \\
\text { in terms of accomplishing a common goal? }\end{array}$ & 0.160 & 0.905 \\
\hline & OP3 & $\begin{array}{l}\text { Do you believe that having a positive working relationship with management } \\
\text { helps employee and organizational performance in terms of attaining a common } \\
\text { goal? }\end{array}$ & 0.523 & 0.709 \\
\hline & OP4 & $\begin{array}{l}\text { Do you believe that rewarding employees for their } \\
\text { employee and organizational performance in terms of }\end{array}$ & 0.095 & 0.942 \\
\hline & OP5 & company send its employees for training? & 0.249 & 0.873 \\
\hline & OP6 & employees? & 0.141 & 0.811 \\
\hline & OP7 & The hotel manager manages the tasks in & 0.217 & 0.856 \\
\hline & OP8 & are established in part by the staff. & 0.272 & 0.565 \\
\hline & OP9 & $\begin{array}{l}\text { The hotel management is anxious about meeting objectives within a certain } \\
\text { time frame. }\end{array}$ & 0.071 & 0.833 \\
\hline & OP10 & ger in such a way that they are measurable. & 0.338 & 0.725 \\
\hline & OP11 & $\begin{array}{l}\text { My company has both tangible and intangible assets that have helped it become } \\
\text { more profitable. }\end{array}$ & 0.053 & 0.748 \\
\hline & OP12 & The organization meets its objectives in a timely manner. & 0.418 & 0.712 \\
\hline & OP13 & $\begin{array}{l}\text { Over the previous three years, new product development at my company has } \\
\text { improved. }\end{array}$ & 0.538 & 0.556 \\
\hline & OP14 & $\begin{array}{l}\text { My organization now offers a greater number of effective and creative products } \\
\text { and services. }\end{array}$ & 0.022 & 0.589 \\
\hline & OP15 & The effectiveness of the organization's operations has improved. & 0.132 & 0.893 \\
\hline & OP16 & The number of customers in my organization has increased. & 0.465 & 0.709 \\
\hline & & In the last two years, we've been able to reach and exceed our reve & 0.384 & 0.839 \\
\hline & OP18 & Over the previous two or three years, profitability has improved. & 0.032 & 0.780 \\
\hline & OP19 & Market share growth has surged in my company. & 0.465 & 0.588 \\
\hline
\end{tabular}

Source: Researcher's Computation

To strengthen the strength of the factors, factor analysis was performed (Table 3.1.) with one as the Eigenvalue. When the rotation converged in its iterations, three factors were retrieved. OKR practices and Organisational Performance (OP) were the two variables. The questionnaire's 37 questions were categorized as 
a measure of OKR's effectiveness in improving organizational performance. The research analysis yielded a three-factor solution with Eigenvalues over one that accounts for $58 \%$ of the total variation, compared to $18 \%$ for the researchers. This suggests that when more items are developed, more factors can influence OKR and OP. The Kaiser Meyer Olkin (KMO) was 0.622, indicating a good level, and the study variables are high, with good measurement quality, and thus suited for investigating the study variables. Based on the rotated component matrix, the Measurement of Sampling Adequacy (MSA) for all 37 items was found to be more than 0.7 on aggregate.

The primary data were analysed using the SPSS version 25. The descriptive statistics were the mean and standard deviation while the inferential statistics included correlation and coefficient of determination to determine the effect of the independent variable on the dependent variable. The statistical model used was:

$\mathrm{Y}=\mathrm{a}+\mathrm{bx}+\varepsilon$

This is specified thus as:

$\mathrm{OP}=\alpha+\beta_{1} \mathrm{OKR}+\varepsilon$

Where:

$\mathrm{OP}=$ Organisational Performance; $\alpha=$ intercept or constant; $\beta=$ Coefficient; OKR $=$ Objectives and Key Results; $\varepsilon=$ Error Term

\section{Data Analysis and Presentation}

\subsection{Descriptive Statistics}

To establish the effect of Objectives and Key Results (OKR) on Organisational Performance (OP), a Likert scale data was collected which rates the degree of the agreement on the scale of 1 to 5 -where 1 is the strongly disagree and 5 is the strongly agree. The results from the collected responses were analysed with mean and standard deviations.

Table 4.2.: Descriptive statistics of the questionnaire

\begin{tabular}{|c|c|c|c|c|c|}
\hline \multicolumn{3}{|c|}{ Variables } & Mean & $\begin{array}{l}\text { Standard } \\
\text { Deviation }\end{array}$ & Grade \\
\hline \multirow{13}{*}{ 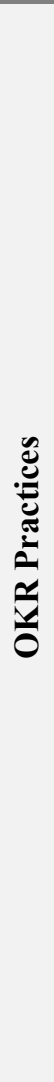 } & OKR1 & $\begin{array}{l}\text { Developing the hotel's goals in light of modern } \\
\text { technologies. }\end{array}$ & 3.9 & 0.612 & Agree \\
\hline & OKR2 & $\begin{array}{l}\text { Keeping and inspiring employees to achieve hotel goals on } \\
\text { a continuous basis. }\end{array}$ & 3.6 & 0.908 & Agree \\
\hline & OKR3 & $\begin{array}{l}\text { Building shared decision-making and peer support among } \\
\text { individuals with adequate authority and responsibility for } \\
\text { effective management by the organization. }\end{array}$ & 3.7 & 0.683 & Agree \\
\hline & OKR4 & $\begin{array}{l}\text { Unleashing the potential that currently exists in the } \\
\text { workforce with objectives and key results (OKR) technique. }\end{array}$ & 3.7 & 0.653 & Agree \\
\hline & OKR5 & $\begin{array}{l}\text { The efficiency with which the hotel services development } \\
\text { strategy was carried out involves OKR. }\end{array}$ & 3.9 & 0.806 & Agree \\
\hline & OKR6 & Aligning individual goals with organisational goals. & 3.6 & 0.836 & Agree \\
\hline & OKR7 & $\begin{array}{l}\text { Designing, implementing and assessing the hotel's } \\
\text { objectives. }\end{array}$ & 3.5 & 1.010 & Agree \\
\hline & OKR8 & $\begin{array}{l}\text { Developing the organizational structure and operational } \\
\text { procedures for employee evaluations. }\end{array}$ & 3.7 & 0.643 & Agree \\
\hline & OKR9 & $\begin{array}{l}\text { Because your hotel implemented OKR, it is fulfilling its } \\
\text { goals and your goals. }\end{array}$ & 3.4 & 1.102 & Neutral \\
\hline & OKR10 & $\begin{array}{l}\text { A team that is respected, energized, and capable of achieving } \\
\text { goals. }\end{array}$ & 3.1 & 0.989 & Neutral \\
\hline & OKR11 & $\begin{array}{l}\text { Activating workers' and the community's active } \\
\text { participation in hotel management. }\end{array}$ & 2.9 & 0.724 & Neutral \\
\hline & OKR12 & $\begin{array}{l}\text { Employees' readiness to seek feedback monthly as against } \\
\text { annually or never on their own job performance. }\end{array}$ & 2.8 & 0.714 & Neutral \\
\hline & OKR13 & $\begin{array}{l}\text { Staff taking proactive actions to boost their own } \\
\text { development. }\end{array}$ & 3.8 & 0.755 & Agree \\
\hline
\end{tabular}




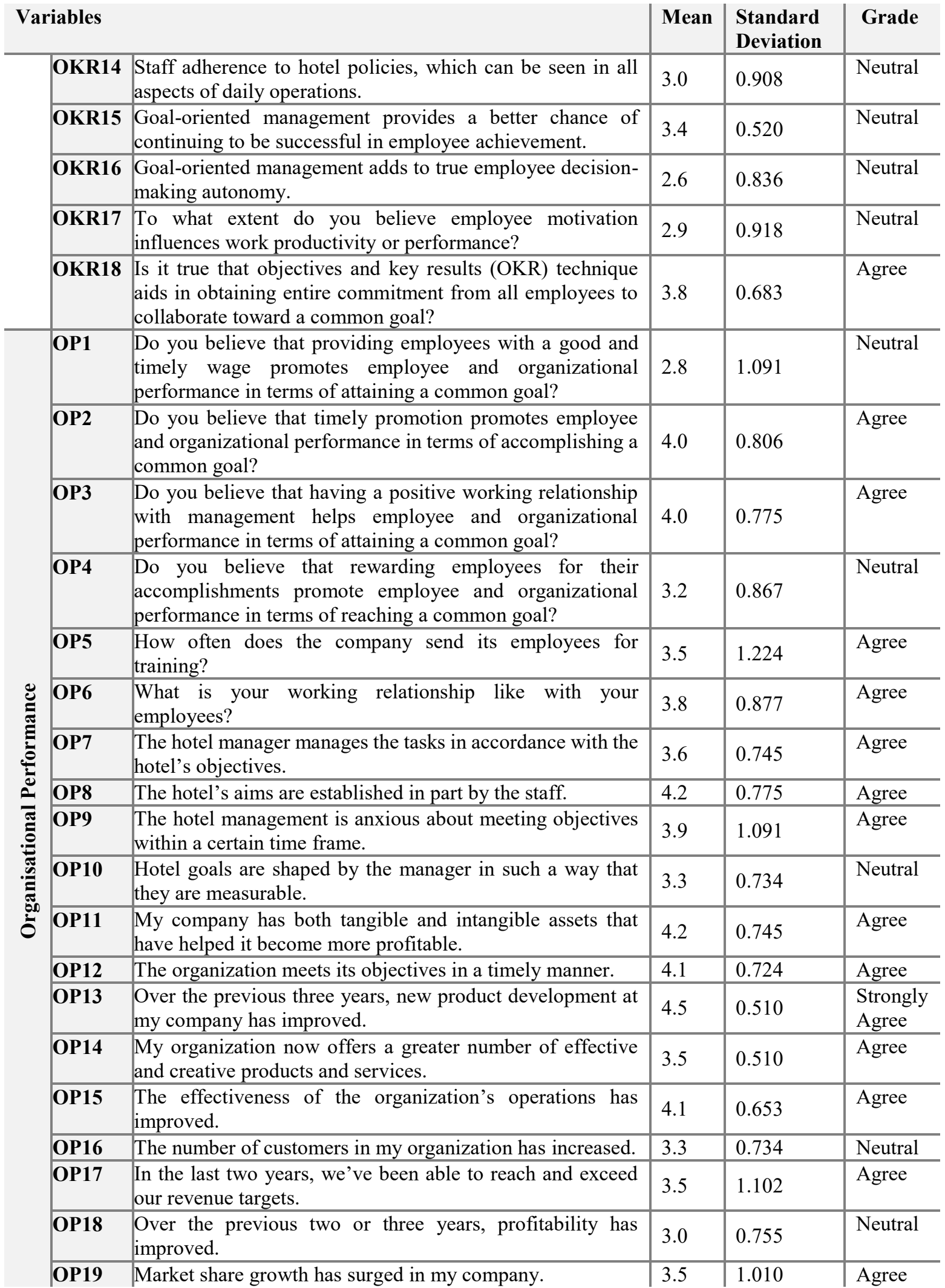

Source: Researcher's Computation

The results in Table 4.1., show the mean responses and standard deviation on OKR on organisational performance. From table 4.1, several of the respondents agreed on the implementation of OKR practices in their organisation, whilst others were neutral about their opinion. Meanwhile, the majority of the respondents agree that there is improvement in the organisational performance of their hotels. 


\subsection{Inferential Statistics}

Table 4.2.: Correlation matrix relationship between OKR and OP using principal component analysis (PCA)

\begin{tabular}{l|l|l|l}
\hline & & OKR & OP \\
\hline OKR & PCA & 1 & $0.421^{* *}$ \\
& Sig. (2-tailed) & 0.000 & 0.000 \\
\hline OP & PCA & $0.421^{* *}$ & 1 \\
& Sig. (2-tailed) & 0.000 & 0.000
\end{tabular}

Source: Researcher's Computation

The results in Table 4.2., show the correlation matrix relationship between OKR and organisational performance (OP) using principal component analysis (PCA) at 0.05 significance. The PCA technique was used since it finds the underlying correlations that exist in a potentially very large set of variables. From table 4.1 , it shows a moderately positive relation between OKR practices and organisational performance. This goes to show that employees are moderately convinced that the need of achieving the management objectives is related to the OKR management technique.

Table 4.3.: Model Summary Model Summary

\begin{tabular}{lllll} 
Model & Multiple R & R Square & $\begin{array}{l}\text { Adjusted } \\
\text { Square }\end{array}$ & $\begin{array}{c}\text { R Standard Error of } \\
\text { the Estimate }\end{array}$ \\
\hline 1 & $0.593^{\text {a }}$ & 0.351 & 0.348 & 0.53825 \\
\hline
\end{tabular}

a. Predictors: (Constant), OKR

Source: Researcher's Computation

As shown in Table 4.3, the Multiple $\mathrm{R}$ of 0.593 , indicates a strong linear effect on the independent variable and the dependent variable. The model also has an $\mathrm{R}$ Square of 0.351 meaning that the independent variable (OKR) explains about $35.1 \%$ of the variability of the dependent variable (OP) - it further shows that other proxies that may affect employee performance not tested in the study amount to about $64.9 \%$. The Adjusted $\mathrm{R}$ Square was 0.348 , an indication that there was a variation of $34.8 \%$ on the organisational performance due to changes in the OKR practices.

Table 4.4.: Analysis of Variance (ANOVA)

\section{ANOVA}

\begin{tabular}{llllllll} 
Model & & Sum of Squares & df & Mean Square & F & Sig. \\
\hline 1 & Regression & 32.142 & 1 & 32.142 & 110.944 & $0.000^{\mathrm{b}}$ \\
\cline { 2 - 7 } & Residual & 59.392 & 205 & 0.290 & & \\
\cline { 2 - 5 } & Total & 91.534 & 206 & & & \\
\hline
\end{tabular}

a. Dependent Variable: OP

b. Predictors: (Constant), OKR

Source: Researcher's Computation

From the ANOVA table in Table 4.4, the processed data had a significance level of 0.000 . This shows that the data is ideal for concluding the population parameters as the value of significance ( $p$-value) is less than 0.05 .

Table 4.5.: Coefficient of Determination

\section{Coefficients $^{\mathrm{a}}$}

\begin{tabular}{|c|c|c|c|c|c|c|}
\hline \multirow{2}{*}{\multicolumn{2}{|c|}{ Model }} & \multicolumn{2}{|c|}{ Unstandardized Coefficients } & \multicolumn{2}{|c|}{$\begin{array}{l}\text { Standardized } \\
\text { Coefficients }\end{array}$} & \multirow[b]{2}{*}{ Sig. } \\
\hline & & $\mathrm{B}$ & Std. Error & Beta & $\mathrm{t}$ & \\
\hline 1 & (Constant) & 2.140 & 0.160 & & 13.334 & 0.000 \\
\hline & OKR & 0.488 & 0.046 & 0.593 & 10.533 & 0.000 \\
\hline
\end{tabular}

a. Dependent Variable: OP

Source: Researcher's Computation

From Table 4.5 above, and in line with Equation (3.2), the statistical model could be represented as:

$2.140=\alpha+0.488 \mathrm{OKR}+\varepsilon$ 
By analysing the regression coefficient between organisational performance (OP) as an independent variable and OKR as a dependent variable (Table 4.5 ), we found a regression coefficient beta $=0.488$ for OKR. Following Table 4.5, it was revealed that holding the OKR practices in hotels to a constant zero, Organisational Performance (OP) would stand at 2.140. Nevertheless, the variables reflect that a unit increase in OKR practices would lead to an increase in OP by a factor of 0.488 ; with it being significant at 0.000 . As such, the null hypothesis for the study is rejected in favour of the alternate hypothesis.

Thus, this implies that whenever there is an application of management strategies with goals, which include relying on technological means in management; continuous motivation of workers and support for the process of delegating authority to employees; monitoring of monthly key results amongst others, has led to the development of the organisational performance of the researched hotels. Consequently, it led to the achievement of the previously planned goals.

\section{Conclusion}

The study assessed the effect of objectives and key results (OKR) management technique on organisational performance in selected hotels in Abuja, Nigeria. The study concluded that OKR has a positive significant effect on organisational performance. From the findings, hotels fulfilled their goals by using OKR practices, which requires managers to collaborate with their subordinates to define and clarify performance goals and key results that are aligned with the work unit's and the organization's overall goals. As such, the OKR is not just a goalsetting management technique for the .com companies, it also applies to the hospitality industry. This finding is in tandem with the works of Teo and Low (2016), who reported that goal setting has an impact on employee effectiveness and ultimately improves organizational effectiveness. OKR helps develop the hierarchy of objectives as a set of well-defined chains when this approach is followed at all levels of the organization. OKR contributes to the creation of a dynamic environment for both management and staff by encouraging contact between heads and subordinates and motivating them to effectively participate in the hotel's aims.

Hotels management who may be employing OKR practices and are not performing well may be as a result of them not employing the OKR framework aright. Also, it could be a result of other factors like management or leadership style, diversity amongst others. Since the OKR management technique has been empirically shown to have an effect on organisational performance, the study recommends activating and implementing OKRs in hotel establishments due to its numerous benefits that help to the positive development of organization's performance - reaching its desired profitability and boosting the organization's long-term viability. 


\section{References}

Adeola, O. \& Ezenwafor, K. (2016). The hospitality business in Nigeria: issues, challenges and opportunities. Worldwide Hospitality and Tourism Themes, 8(2): 182-194.

Baker, S., Bradley, P., \& Huyton, J. (2011). Principles of hotel front office operations. Hampshire: Cengage Learning.

Business Dictionary (2007, January 30). How has this term impacted your life? Retrieved October 31, 2021, from http://www.businessdictionary.com/definition/objective.html

Business Dictionary (2007, January 30). What is hospitality industry? definition and meaning. Retrieved October 27, 2018, from http://www.businessdictionary.com/definition/hospitality-industry.html

Caan, J. (2014, March 5). To succeed in hospitality, focus on the customer. The Guardian. Retrieved October 22, 2021, from https://www.theguardian.com/small-business-network/2014/mar/05/succeed-hospitality-focus-customer-james-caan

Caramela, S. (2018, March 16). 4 Ways to Implement Peter Drucker's Theory of Management. Retrieved October 29, 2021, from https://www.businessnewsdaily.com/10634-peter-drucker-management-theory.html

Chathoth, P. K., \& Olsen, M. D. (2007). Does corporate growth really matter in the restaurant industry? International Journal of Hospitality Management, 26(1), 66-80. doi:10.1016/j.ijhm.2005.09.004

Cho, J., \& Dansereau, F. (2010). Are transformational leaders fair? A multi-level study of transformational leadership, justice perceptions, and organizational citizenship behaviors. The Leadership Quarterly, 21(3), 409-421

Crawford, A., \& Hubbard, S. S. (2008). The impact of work-related goals on hospitality industry employee variables. Tourism and Hospitality Research, 8(2), 116-124.

Drucker, P. F. (1954). The practice of management: A study of the most important function in America society. New York: Harper \& Brothers.

Duggan, K. (2015). Getting Started with Objectives \& Key Results (OKRs). Retrieved October 22, 2018, from https://static1.squarespace.com/static/5a86c8eaf43b55c5a1945f70/t/5ac777c2aa4a9945f394d501/1523021768605/OKR Guide Betterworks.pdf

First Round Review (2015, February 07). The Management Framework that Propelled LinkedIn to a \$20 Billion Company. Retrieved October 21, 2021, from https://firstround.com/review/the-management-framework-that-propelled-LinkedIn-to-a-20-billioncompany/

Gall, M. D., Borg, W. R., \& Gall, J. P. (2006). Educational research: An introduction (8th ed.). Boston: Pearson.

Gilb, T. (2017, February 2). OKR Objectives and Key Results: What's wrong and how to fix it. Retrieved October 28, 2021, from file://C:/Users/SCOTCH 1.SCO/AppData/Local/Temp/1532942921737.pdf

Grove, A. S. (1983). High output management: An organisational Baedeker for managers at all levels. TestOrt: Biddles of Guildford.

Hess, A. (2017, August 25). How To Set And Obtain Goals In The Restaurant Business. Retrieved October 21, 2021, from https://www.joinforge.com/set-obtain-goals-restaurant-business/

Hogan, J. (2011, April 7). Delivering Hospitality with Management by Objectives | By Dr. John Hogan - Hospitality Net. Retrieved October 23, 2018, from https://www.hospitalitynet.org/opinion/4050910.html

Holliman, A. E. \& Bouchard, M. (2015). The Use of Management by Objectives in Municipalities: Still Alive?. Review Public Administration Management, 3, 150. doi:10.4172/2315-7844.1000150

Kaljundi, J. (2014, September 18). OKR: Objectives and Key Results - Resources, Templates, Tutorial, Software. Retrieved October 21, 2021, from https://weekdone.com/resources/objectives-key-results

Lauková J. (2006). Hospitality Management (Unpublished master's thesis). Masaryk University, Brno, Duben.

Locke, E. A. (1968). Towards a theory of task motivation and incentives. Organizational Behavior and Human Performance, $3,157-189$.

Mastrangelo, A., Eddy, E. R., \& Lorenzet, S. J. (2014). The relationship between enduring leadership and organizational performance. Leadership and Organization Development Journal, 35(7), 590-604.

Niven, P. R., \& Lamonte, B. (2017). Objectives and key results: Driving focus, alignment, and engagement with OKRs. Hoboken, New jersey: John Wiley \& Sons.

Pawar, Y. (2016, June 14). What is the difference between MBO and OKR. Retrieved October 24, 2021, from https://upraise.io/blog/difference-mbo-okr/

Pizam, A., \& Shani, A. (2009). The Nature of the Hospitality Industry: Present and Future Managers' Perspectives [Abstract]. International Journal of Tourism and Hospitality Research, 20(1), 134-150.

PKF Consulting (1997). “Trends”. PKF Consulting, pp 1-3.

Popova, D. (2012). Hospitality Management. Retrieved October 24, 2021, from http://vfu.bg/en/eLearning/HOSPITALITY_MANAGEMENT.ppt

Teo, T. P., \& Low, K. P. (2016). The Impact of Goal Setting on Employee Effectiveness to Improve Organisation Effectiveness: Empirical study of a High-Tech Company in Singapore. Journal of Business \& Economic Policy, 3(1), 82-97.

Tomal, D. R., \& Jones, K. J. (2015). A comparison of core competencies of women and men leaders in the manufacturing industry. The Coastal Business Journal, 14(1), 13-25.

Wodtke, C. R. (2016). Radical Focus: Achieving Your Most Important Goals with Objectives and Key Results. New York: Cucina Media LLC. 